\section{Magnetic prospecting of the Roman military camp at Septimer Pass (Switzerland)}

\author{
Jörg W.E. Fassbinder, ${ }^{1}$ Rob Sternberg, ${ }^{2}$ \\ Werner Zanier, ${ }^{3}$ Doris Ebner, ${ }^{1}$ \\ Jürg Rageth ${ }^{4}$ \\ 'Bavarian State Department of \\ Monuments and Sites, Munich, Germany; \\ 2Earth and Environment Department, \\ Franklin \& Marshall College, Lancaster, \\ PA, USA; ${ }^{3}$ Bavarian Academy of Science, \\ Munich, Germany; ${ }^{4}$ Archaeological \\ Service, Graubünden, Switzerland
}

\section{Abstract}

The Roman military encampment at the Septimer Pass (near Bivio, Switzerland) was located in 2003 using metal detectors. Dating between $15 \mathrm{BCE}$ and $16 \mathrm{CE}$, the camp was designed for controlling the Pass, and to enable the movement of Roman troops between Italy and the northern province of Raetia. The 2-ha sized site was delineated by topography, aerial photographs, visible fortification walls and ditches, and the locations of finds. Subsequent trench excavations by the Bavarian Academy of Science were limited to $150 \mathrm{~m}^{2}$. Although these excavations provided a better understanding of the construction of the fortification walls, they gave no idea about the overall layout of tents or other buildings. For this study, magnetometry with a cesium-magnetometer in a duo-sensor configuration was used to survey an area of $160 \times 120 \mathrm{~m}$ at a sampling interval of $25 \times 50 \mathrm{~cm}$. Some magnetic anomalies suggest geologic lineaments and modern cultural sources. Other anomalies support visual evidence of fortifications, suggest the outline of wooden barracks or contubernia used for military housing, and possibly the locations of watchtowers, pits and fireplaces. The magnetically clean zones between these anomalies correlate with the occurrence of tent nails that were found and cleared by the earlier metal detectorists, suggesting that these areas were primarily used for tents.

\section{Introduction}

The reign of Augustus, the first emperor of Rome, was marked by a number of major military campaigns, resulting in a major expansion of the Roman Empire. The Alpine Campaigns in 16-15 BCE subdued various hostile tribes throughout the Alps as part of the conquests of Noricum (roughly modern day Austria) and
Rhaetia (roughly eastern Switzerland and southeastern Germany). Gruen (1990) suggests that the Alpine Campaign was not necessarily strategically linked to subsequent conquests, but may have been carried out to facilitate communications with the army beyond the Alps, and to refine the soldiering of his stepsons Drusus and Tiberius. Augustus celebrates his accomplishment of pacifying the Alps from the Adriatic to the Tuscan (Tyrrhenian) Sea in his Res Gestae (funeral inscription).

Septimer Pass is one of twelve major Alpine passes, one of only two or three passes in the Graubünden Alps known to the Romans, and the most important one in this region until the middle of the first century. It is located $6 \mathrm{~km}$ south of the village of Bivio, in the Swiss canton of Graubünden (Figure 1), at an elevation of $2340 \mathrm{~m}$ asl. The Roman encampment at Septimer Pass studied here lies on a 2-hectare knob with a local topographic relief of $30 \mathrm{~m}$.

High precision magnetometry is one of the major methods of geophysics used to survey archaeological sites and landscapes (Kvamme, 2001; Gaffney and Gater, 2003; Aspinall et al., 2008; Gaffney, 2008). There is published work on geophysical surveys at Roman forts (Biggins et al., 1999; Biggins and Taylor, 2004; Hopewell et al., 2005; Drahor et al., 2008; Gaffney and Gater, 2003), but none we are aware of on temporary military camps. This paper discusses results of field magnetometry at Septimer Pass, and the complementarity of these geophysical results with the earlier archaeological excavation.

\section{Archaeology}

Only in the last 20 years have any artifacts from the Alpine Campaigns been identified. The site at Septimer Pass is the only known site of a Roman camp in this region (Figure 1, \#27). At $2345 \mathrm{~m}$ above sea level, it is also the highest altitude Roman camp known in the whole empire.

In 2004, metal detectorists located several lead slingshot projectiles, other Roman weapons, and over 400 shoe nails, scattered over the site, and not georeferenced; these were brought to the attention of canton authorities and Zanier. Along with finds at another nearby site (Crap-Ses Schlucht), these were the first archaeological evidence for a military presence in the Alps during the Alpine Campaigns. Archaeological excavation took place in 2007-08, and has been completed (Zanier, 2006, 2009). Geophysics was discussed at that time, but was ruled out because of the thin Alpine soils. After Zanier and Fassbinder met later on, they decided nonetheless to carry out a geophysical survey. The geophysics followed the excavation, reversed from the usual order, which did not allow the excavation to benefit from the geophysics. As was
Correspondence: Rob Sternberg, Earth and Environment Department, Franklin \& Marshall College, 415 Harrisburg Ave, Lancaster, 17604 PA, USA.

Tel. +1.717.291.4134 - Fax: +1.717.291.4186.

E-mail: rob.sternberg@fandm.edu

Key words: geophysics, magnetometry, Roman, Switzerland, Augustus.

Acknowledgments: Author Rob Sternberg thanks Franklin \& Marshall College for a sabbatical leave, and the Bavarian State Department of Monuments (BLDM) and Sites (Bayerische Landesamt für Denkmalpflege) for hosting his visit. Lena Kühne (BLDM) assisted with the data processing and plotting.

Contributions: JWEF was chief of the geophysics work; WZ directed the archaeological excavation; JR supported the archaeological work with resources of the canton; $\mathrm{RS}$ and DE assisted with the field work; and RS wrote the article.

Conflict of interests: the authors declare no potential conflict of interests.

Citation: Fassbinder JWE, Sternberg R, Zanier W, Ebner D, Rageth J, 2014. Magnetic prospecting of the Roman military camp at Septimer Pass (Switzerland). In: RH Tykot (ed.), Proceedings of the $38^{\text {th }}$ International Symposium on Archaeometry - May $10^{\text {th }}-14^{\text {th }} 2010$, Tampa Florida. Open Journal of Archaeometry 2:5303.

Presented at the $38^{\text {th }}$ International Symposium on Archaeometry - May $10^{\text {th }}-14^{\text {th }} 2010$, Tampa, Florida.

This work is licensed under a Creative Commons Attribution 3.0 License (by-nc 3.0).

(C) Copyright J.W.E. Fassbinder et al., 2014 Licensee PAGEPress, Italy

Open Journal of Archaeometry 2014; 2:5303

shown by Fassbinder (2010) for Roman forts, this approach can still provide useful complementary pictures of a site, and additional information that could be used by any future excavators

Altogether, the metal detecting located 23 slingshot bullets, 72 nails (tent pegs), and 63 coins, as well as debris from use of the area by the Swiss military from 1960-2000. The nails are consistent with the Roman military units of contubernia, which had eight soldiers living in tents of leather, with 16-20 iron nails per tent. Each tent was $3 \times 3 \mathrm{~m}$, with fires outside. The coins were especially useful for dating the use of the camp from 15-16 BCE to $16 \mathrm{CE}$. Altitude and weather would have limited use of the camp to the more temperate summer months.

The archaeological excavations in 2007 and 2008 (Zanier, 2009) were limited to ten trench- 
es over a total area of $150 \mathrm{~m}^{2}$, the largest of which had an area of $60 \mathrm{~m}^{2}$. The trenches revealed a wall at least $100 \mathrm{~m}$ long, perhaps as long as $180 \mathrm{~m}$, although interior architecture was not clear. It was difficult to make sense of the stratigraphy, but aligned stones were found within the trench walls, as well as burned lenses with charcoal.

\section{Materials and Methods}

The magnetometer survey was conducted over three days in August, 2009, by the coauthors. Procedures developed at the Bayerisches Landesamt für Denkmalpflege by Helmut Becker (1999, 2008) and Jörg Fassbinder (2010) were used. The area of $160 \times 120 \mathrm{~m}$ ( $\approx 2 \mathrm{ha}$ ) was surveyed in $40 \times 40 \mathrm{~m}$ grids, with some odd spaces being filled in by other grid sizes. The instrument used was a cesium vapor magnetometer, with two sensors mounted on a wooden frame, horizontally separated by $0.5 \mathrm{~m}$, and carried about $0.3 \mathrm{~m}$ above the surface. Profiles along and between tapes were walked east-west in a zig-zag fashion, with 1 meter between lines, measurements made every $0.1 \mathrm{~s}$, and marks inserted in the data files at $5-\mathrm{m}$ intervals for better spatial interpolation. Some magnetic susceptibility measurements were made in situ with a portable susceptibility meter.

During data processing, the data were interpolated to a $0.25 \times 0.25 \mathrm{~m}$ grid, and bandpass filtered to reduce high-frequency noise due to geomagnetic micropulsations, although solar activity was low during the time period of the survey. The diurnal variation was removed by line-mean and grid-mean normalisation. The results were displayed in grayscale magnetograms, clipped to emphasise subtler, lower amplitude anomalies.

\section{Results and Discussion}

Figure 2 is a magnetogram for the site. The 10 excavated trenches were scattered across the central part of the map area. The grayscale image is supplemented by red color to mark the highest anomalies, and blue to denote the lowest. The area on the right was actually set at an angle relative to the rest of the grid, but has not been re-positioned in this figure. We note several distinctive types of anomalies, and discuss their possible meaning along with each set of observations.

First, high (500 nT peak-to-peak) N-S oriented dipolar anomalies appear in the southeast [(SA) in Figure 2]. Very high-amplitude $\mathrm{N}-\mathrm{S}$ oriented dipolar anomalies are characteristic of modern ferrous objects. We suggest these could be due to remnants of recent Swiss military maneuvers that were somehow not cleared during the metal detecting.

Second, linear anomalies (Figure 2, L1L1',L2-L2',L3-L3') trending NW-SE with amplitudes of about $50 \mathrm{nT}$. The linear anomalies par- allel a general fabric in the geologic map, so we interpret these as geologic lineaments. The geology of the area is complex, representing an ophiolite complex, including serpentine, diabase, and gabbro (Schweizerische Eidgenossenschaft, 2011). Magnetic suscepti-

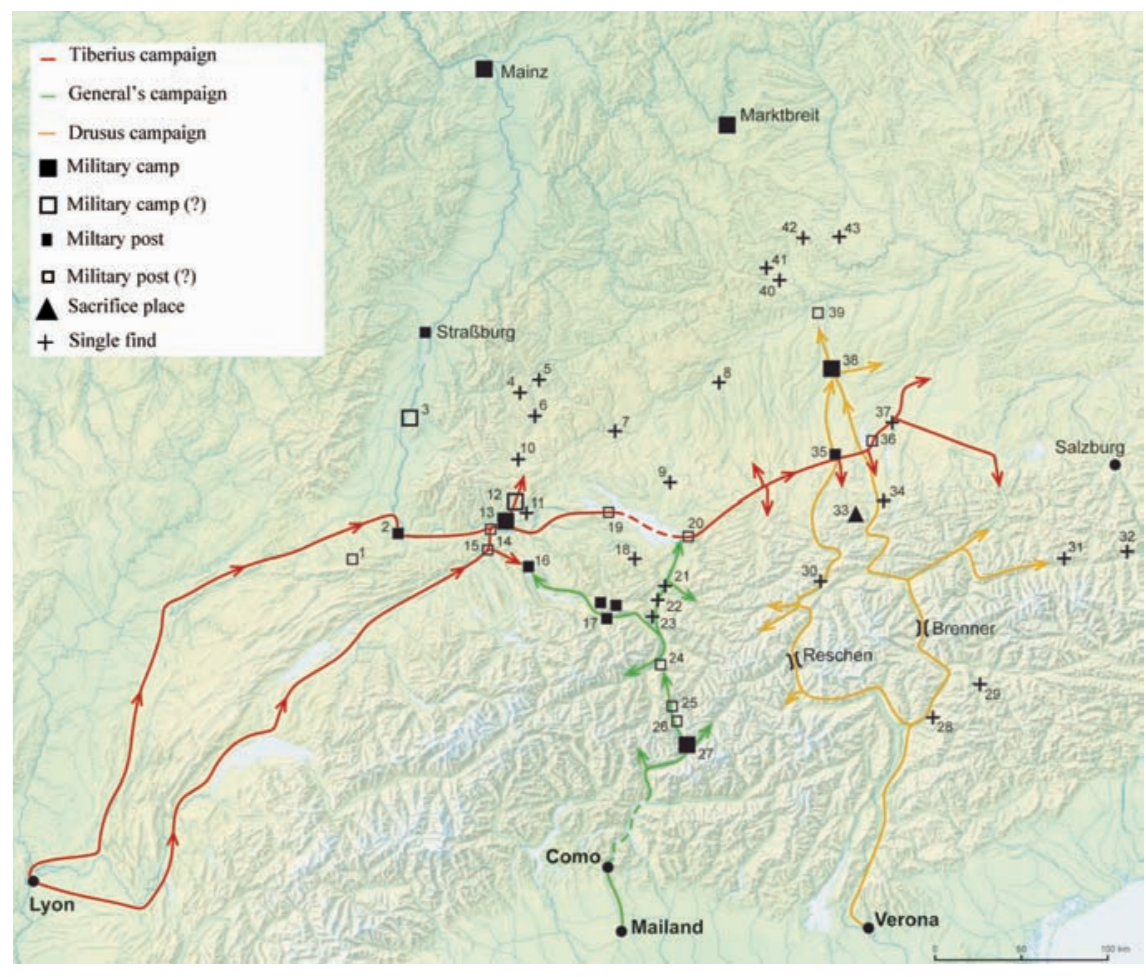

Figure 1. Map of the Alpine region, showing the modern locations of Lyon and Strasbourg (Strassburg), France; Salzburg, Austria; and Verona and Milan (Mailand), Italy. The caption indicates the paths of Tiberius and Drusus in the year $15 \mathrm{BCE}$; military camps, possible military camps, military posts, and possible posts; a sacrificial site; locations of single finds. The site at Septimer Pass is military camp \#27.

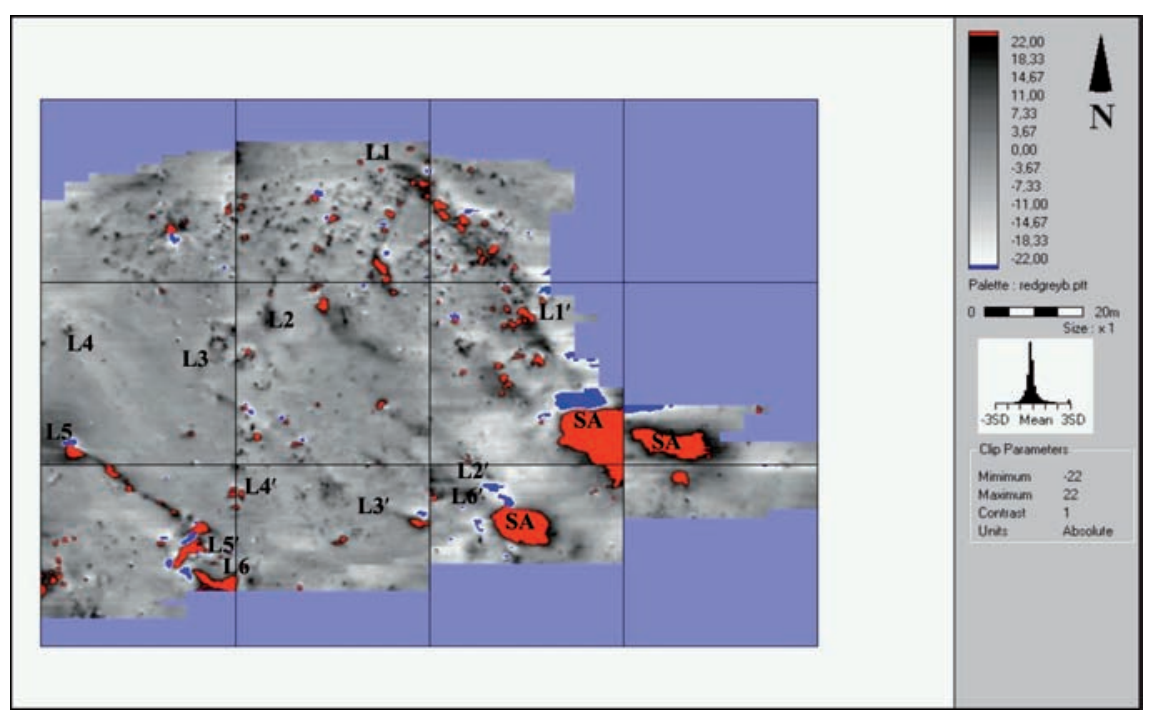

Figure 2. Grayscale magnetogram for Septimer Pass, with the higher anomaly values dark (highest are in red), and the lowest light (lowest are in blue). Each grid is $40 \times 40 \mathrm{~m}$. The area shown is approximately coincident with the plateau comprising the site. Marked anomalies are discussed in the text. 
bility made directly on outcrop at the site showed rock susceptibilities about 6-7 times that of the thin soils.

Third, high amplitude anomalies are found along the southwestern most lineament (Figure 2, L5-L5'), including a $500 \mathrm{nT}$ inverted dipole. High-amplitude anomalies not aligned with the current geomagnetic field suggest a source with remanent magnetisation. These could be due to the presence of ferrous metal, or lightning-induced isothermal remanence (Maki, 2005) on rocks along the geologic lineament.

Fourth, a subtle linear anomaly with an amplitude up to $30 \mathrm{nT}$ (Figure 2, L6-L6'). Archaeological anomalies are often not the highest amplitude features at a site, especially when there has been modern activity. In this case, the linear anomaly corresponds to the location of a topographic high, and a partially excavated rampart fortification. The high magnetic susceptibility of metamorphic bedrock comprising masonry could cause these anomalies.

Fifth, figure 3 shows the magnetogram with anomalies that we judged as significant manually outlined in red. There are three types of geometrically intriguing anomalies. The first are two series of linear anomalies in the orange box in the northeast area of Figure 3, each covering an area of about $20 \times 15 \mathrm{~m}$, striking roughly NE-SW, on either side of the magnetically clean triangular area. We can imagine two alternate archaeological explanations for these aligned positive anomalies. One explanation consistent with other geophysical surveys would be that the individual high anomalies in this area are due either to postholes of a wooden barracks-type building or to storage pits, with the cavities filled with higher susceptibility soil (e.g., Fassbinder and Stanjek, 1993). Such a structure is similar to the interpretation of Biggins et al. (1999) for a barracks. The high susceptibility soil would be consistent with the burned lenses found in the archaeological trenches, since magnetic susceptibility is frequently enhanced by human activity, by burning (Tite and Mullins, 1971; Batt and Dockrill, 1998; Marmet et al., 1999; Morinaga et al., 1999; Peters et al. 2000; Crowther, 2003) or bacterial action (Faßbinder and Stanjek, 1993). However, this interpretation would imply a very large building for such a remote camp. An alternative possibility is that these positive anomalies represent individual fireplaces, adjacent to what could have been $3 \times 3 \mathrm{~m}$ contubernium tent spaces in the magnetically clean area described below.

Sixth, the second interesting geometric anomaly is in the middle of the anomalies described in the preceding point, where there is a $15 \times 13 \times 8 \mathrm{~m}$ triangular area that is magnetically clean. The magnetically clean zone correlates with the locations of tent nails that were found and cleared by the earlier metal detecting. This suggests the possibility that these places could have been primarily used for tents.

Seventh, the third interesting geometric pattern is the square-shaped positive anomaly in the center of the orange box to the southwest (Figure 3), with a smaller central negative

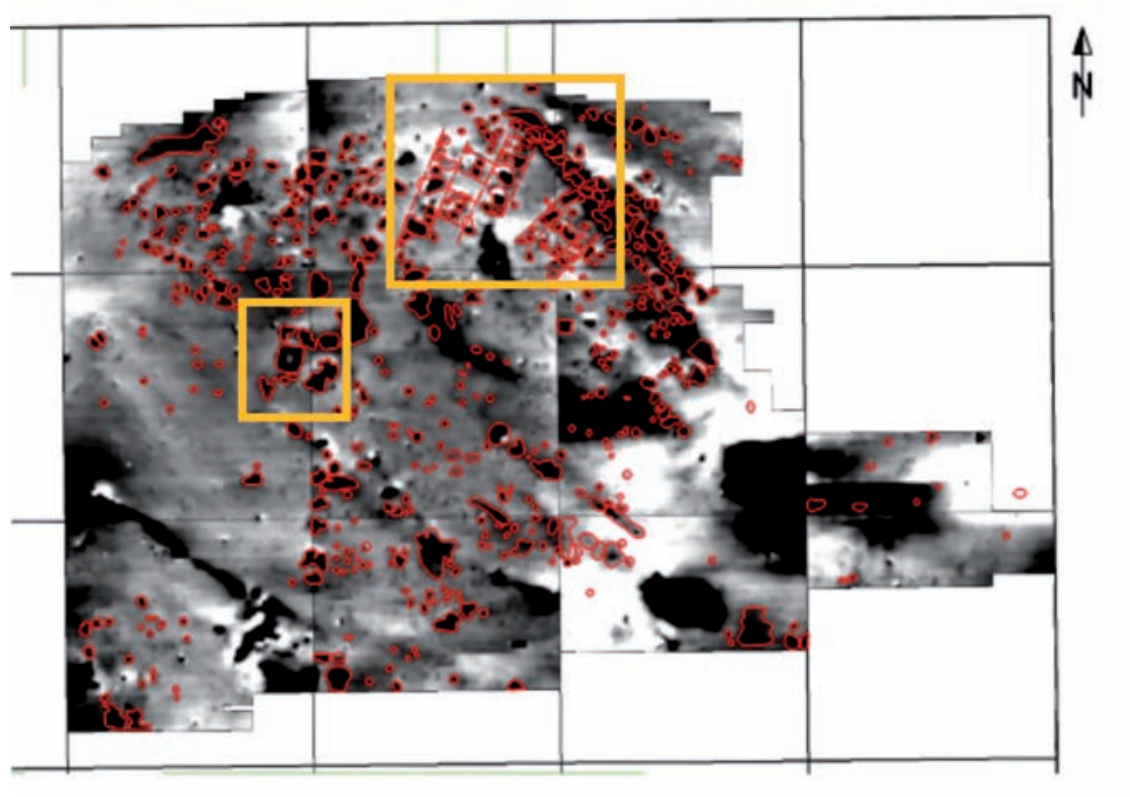

Figure 3. Grayscale magnetogram for Septimer Pass. The scale is $\pm 13 \mathrm{nT}$, with the higher anomaly values shaded dark, and the lower light. Each grid is $40 \times 40 \mathrm{~m}$. Anomalies which appear to be significant have been manually identified in red. The areas outlined in orange correspond to those discussed as anomaly patterns 5, 6 and 7 in the text. anomaly.

Based on similar geophysical anomalies and subsequent excavation elsewhere (Fassbinder, 2010), one of us (JWEF) believes this represents a watchtower. However, another one of us (WZ) is dubious: this topographically elevated location would be a good vantage point without a tower. Importing wood to this site above tree line to construct a watchtower would be costly, and the temperature and wind conditions on such a tower at the pass would be harsh. Based on present knowledge, we are unable to resolve these (or other) possibilities.

\section{Conclusions}

The geophysics complemented the findings in the excavated trenches, which covered only $0.3 \%$ of the area represented by the magnetometry. A variety of geometric anomalies were observed, reflecting a combination of geologic, archaeological, and modern sources. Meaningful archaeological anomalies appear to be present despite the thin nature of the Alpine soils, partly because of the high susceptibility bedrock. Thus, geophysics may be useful in further exploration of short-lived Roman encampments. Conclusive interpretation of anomalies is not always possible when the archaeology, rather than being used for subsequent ground truthing, actually precedes the geophysics, yet the possibility of more definitive identification remains, especially if additional geophysics, micromorphological analysis of soils, or even further excavation are undertaken.

\section{References}

Aspinall A, Gaffney C, Schmidt A, 2008. Magnetometry for archaeologists. AltaMira Lanham, MA, USA.

Batt CM, Dockrill SJ, 1998. Magnetic moments in prehistory: Integrating magnetic measurements with other archaeological data from the Scatness multiperiod settlement. Archaeol Prospect 5:217-27.

Becker H, 1999. Duo- and quadro-sensor configuration for high-speed/high resolution magnetic prospecting with caesium magnetometer. In: J.W.E. Fassbinder, W.E. Irlinger (eds.) Archaeological prospection. Proceedings of the 3rd International Conference on Archaeological Prospection, Munich, pp. 100-5.

Becker H, 2008. Caesium-magnetometry for landscape-archaeology. In: S. Campana, S. Piro, (eds.) Seeing the unseen: geophysics and landscape archaeology. Taylor \& Francis, 0xford, pp. 129-65. 
Biggins J, Taylor DJ, 2004. Geophysical survey of the vicus at Birdoswald Roman fort, Cumbria. Britannia 35:159-78.

Biggins JA, Taylor DJ, Coxon B, Esselmont B, Frank A, Hudson C, McCLoy P, Montgomery E, Robinson J, 1999. A survey of the Roman fort and settlement at Birdoswald, Cumbria. Britannia 30:91-110.

Crowther J, 2003. Potential magnetic susceptibility and fractional conversion studies of archaeological soils and sediments. Archaeometry 45:685-701.

Drahor M, Kurtulmus T, Berge M, Hartmann M, Speidel M, 2008. Magnetic imaging and electrical resistivity tomography studies in a Roman military installation found in Satala archaeological site, northeastern Anatolia, Turkey. J Archaeol Sci 35:259-71.

Fassbinder JWE, 2010. Geophysical prospection of the frontiers of the Roman Empire in Southern Germany, UNESCO World Heritage Site. Archaeol Prospect 17:12939.

Fassbinder JWE, Stanjek H, 1993. Occurrence of bacterial magnetite in soils from archaeological sites. Archaeologia Polona 31:117-28.
Gaffney C, 2008. Buried past: a review of geophysical techniques in archaeology. Archaeometry 50:313-36.

Gaffney C, Gater J, 2003. Revealing the buried past: geophysics for archaeologists. Tempus ed., Stroud.

Gruen, ES, 1990. The imperial policy of Augustus. In: K.A. Raaflaub, M. Toher (eds.) Between republic and empire: interpretations of Augustus and his principate. Univerersity of California Press, Berkeley, pp. 395-416.

Hopewell D, Burman J, Evans J, Ward M, Williams D, 2005. Roman fort environs in North-West Wales. Britannia 36:225-69.

Kvamme KL, 2001. Current practices in archaeogeophysics: magnetics, resistivity, conductivity, and ground-penetrating radar. In: P. Goldberg, V.T. Halliday, C.R. Ferring (eds.) Earth sciences and archaeology. Kluwer/Plenum, New York, pp. 35384.

Maki D, 2005. Lightning strikes and prehistoric ovens: determining the source of magnetic anomalies using techniques of environmental magnetism. Geoarcha eology 20:449-59.
Marmet E, Bina M, Fedoroff N, Tabbagh A, 1999. Relationships between human activity and the magnetic properties of soils: a case study in the Medieval site of Roissyen-France. Archaeol Prospect 6:161-70.

Morinaga H, Inokuchi H, Yamashita H, Ono A, Inada T, 1999. Magnetic detection of heated soils at Paleolithic sites in Japan. Geoarchaeology 14:377-99.

Peters C, Church MJ, Coles G, 2000. Mineral magnetism and archaeology at Galson on the Isle of Lewis, Scotland. Phys Chem Earth 25:455-60.

Schweizerische Eidgenossenschaft, 2011. [Geologisher Datenviewer]. [Website in German]. Available from: http://www. geologieviewer.ch/

Tite MS, Mullins C, 1971. Enhancement of the magnetic susceptibility of soils on archaeological sites. Archaeometry 13:209-19.

Zanier W, 2006. [Der römische Alpenfeldzug über den Septimer 15 v. Chr]. [Article in German]. Akademie Aktuell 1:28-31.

Zanier W, 2009. [Römische Waffenfunde vom Alpenfeldzug 15 v. Chr]. [Article in German]. Tagungen des Landesmuseums für Vorgeschichte Halle 2:89-96. 